\title{
Powder and Solution for Solution for Injection Dosage Form
}

National Cancer Institute

\section{Source}

National Cancer Institute. Powder and Solution for Solution for Injection Dosage Form. NCI Thesaurus. Code C149775.

Sterile powder and sterile solution, both containing active substance(s), intended for the preparation of a solution for injection by dissolving the powder in the solution. 